\title{
Research on the quality assurance of fermented dairy products with addition of bioactive compounds from medicinal plants
}

\author{
Ovidiu Tiţa ${ }^{1 *}$, Adelina Maria Constantinescu ${ }^{2}$, and Mihaela Adriana Tiţa $^{3}$ \\ ${ }^{1}$ University "Lucian Blaga" of Sibiu, Department of Agricultural Sciences and Food Engineering, \\ Ioan Ratiu 7-9, Sibiu, Romania \\ ${ }^{2}$ University "Lucian Blaga" of Sibiu, Department of Agricultural Sciences and Food Engineering, \\ Ioan Ratiu 7-9, Sibiu, Romania \\ ${ }^{3}$ University "Lucian Blaga" of Sibiu, Department of Agricultural Sciences and Food Engineering, \\ Ioan Ratiu 7-9, Sibiu, Romania
}

\begin{abstract}
Fermented dairy products are highly appreciated due to the benefits that bring to consumers' health and because they can be eaten at an early age. Extracts of medicinal plants have been used since antiquity, including in the treatment of digestive diseases. These medicinal plants bring many benefits to consumers and they help to treat numerous digestive disorders, diseases caused by stress or irritation of the skin. The objective of this research is to identify hazards, to assess risks and to establish critical control points from the technological flow of obtaining fermented dairy products with the addition of bioactive compounds from medicinal plants. The methods used to conduct research are different qualitative analysis tools because bioactive compounds from medicinal plants require more special processing conditions.
\end{abstract}

\section{Introduction}

Fermented dairy products are highly appreciated due to the benefits that bring to consumers health. They can be eaten at an early age and one of the most famous dairy products from this category is yogurt, which has evolved a lot over time. Industrial production of yogurt incorporating microorganisms was initiated by Isaac Carasso in 1919. Between the 1920s and 1930s, most of the time the yogurt flavor was described as having poor flavor due to its high acidity. Before the 1960s, yogurt was found only in a few grocery stores. In present, many forms of yogurt can be found including plain yogurt, fruit flavored yogurt, drinkable yogurt, frozen yogurt and Greek yogurt with different fat contents [1]. Yogurt is produced by the lactic acid fermentation of milk by addition of a starter culture containing Streptococcus and Lactobacillus species. In 2005, McKinley has reported that yogurt is an important source of calcium, protein, phosphorus, thiamin (vitamin $\mathrm{B}_{1}$ ), riboflavin (vitamin $\mathrm{B}_{2}$ ) and a valuable source of niacin, magnesium and zinc [2].

\footnotetext{
* Corresponding author: ovidiu.tita@ulbsibiu.ro
} 
Yogurt is an important source of bioactive peptides which are formed during fermentation, but generally has limited antioxidant activity.

For this reason, in recent times, it's a great interest to produce yogurt with natural antioxidants [3].

Bioactive food components have multiple beneficial effects on many diseases and are usually found in multiple forms such as glycosylated, esterified, thiolated or hydroxylated [2]. Extracts from different medicinal plants have been used since antiquity, in religious ceremonies, in aromatherapy and in the treatment of various digestive diseases [4]. For a better nutritional and functional improvement, extracts of many plants, fruits, herbs and mushrooms rich in bioactive compounds are increasingly used as additives in yogurt. For example, many researchers have used a crude extract from artichoke, grape extract, tea infusions, seaweed extract, spirulina, Lycium barbarum extract, Pleurotus ostreatus extract, black tea extract and mangosteen extract (Garcinia mangostana Lin.). Herbal nutraceuticals are an alternative for people who want to prevent and treat certain diseases. Therefore, in the recent past, it has been an increase in the demand for herbal medicines in various food products, especially in yogurt [3].

Basil (Ocimum basilicum L.) is part of the Lamiaceae family and is widely used in culinary art. O. basilicum is known in Algeria under the name lahbeq, and in Arabia under the name rehan and it's originally native to India and other Asian countries. Today, it is cultivated all over the world. Traditionally, the basil leaves are used in folk medicine as a remedy for a large number of diseases, including cancer, diarrhea, nausea, gout, convulsion, sore throat, toothaches, epilepsy and bronchitis [5]. According to Marwat et al. (2011), basil has a high protein content $(3.15 \mathrm{~g} / 100 \mathrm{~g})$, Vitamin C (18 mg/100 g), Vitamin E, Vitamin A, Vitamin K, Calcium (177 mg/100 g), Iron (3.17 mg/ 100g), Magnesium (64 mg/100g), and Sodium. Following several in vitro studies, basil volatile oil has been reported to have antimicrobial, antifungal, anticancer, and antioxidant activities [6].

Fennel (Foeniculum vulgare Mill.) is an aromatic plant belonging to the Apiaceae family and it has been cultivated all over the world since ancient times. Fennel seeds have particular economic importance, as they are widely used in the pharmaceutical, food and cosmetic industries. Also, fennel seeds are a rich source of fiber, protein, vitamins, sterols, and phenolic compounds [7]. Following several studies, it has been found that fennel volatile oil is very well preserved due to its antioxidant, antimicrobial and hepatoprotective properties. Fennel volatile oil is effective against various pathogens that cause food poisoning, so it can be used as a natural preservative [8].

Peppermint (Mentha piperita L.) is part of the Lamiaceae family and is cultivated all over the world. According to Capuzzo and Mafei (2016), peppermint is a hybrid between water mint (Mentha aquatica L.) and spearmint (Mentha spicata L.). According to a report prepared by FAOSTAT in 2014 on peppermint production, it increased almost 4 times more than in 1990 (92,295 tons in 2014 and 28,672 tons in 1990). The world's largest production was recorded in Asia (92.23\%), followed by America with a 7.61\% contributes. Peppermint is one of the most popular medicinal plants, and many studies have reported its beneficial effects on health [9]. Most often, peppermint volatile oil is used for therapeutic purposes. It is extracted from the aerial side of the plant and is composed of: menthol (29$48 \%$ ), menthone (20-31\%), menthofuran (6.8\%), menthyl acetate (3-10\%), caffeic acid, flavonoids $(12 \%)$, polymerized polyphenols $(19 \%)$, carotenes, tocopherols, choline and tannins. In traditional medicine it is used as an antiseptic, antispasmodic and also in the treatment of cancer, colds, cramps, indigestion, nausea, sore throat and toothaches. In vitro, peppermint has antibacterial activity against Gram-positive and Gram-negative bacteria, antifungal activity, antiviral activity and an important antioxidant activity [10].

Lavender (Lavandula angustifolia) is an aromatic plant of the Lamiaceae family and it is used for the relief of stress and anxiety. The genus Lavandula includes more than 30 
species and it is widely distributed in the archipelagoes of the Atlantic Ocean and in the lands surrounding Mediterranean Sea. In a recent study, lavender oil was found to be more potent than ibuprofen in relieving stress related disorders in rats subjected to restraint stress. Lavender aromatherapy has also been proven to reduce preoperative anxiety or anxiety in postmenopausal women [11]. In vitro tests have shown that lavender volatile oil has analgesic and anesthetic effects, and it can improve the memory and health of people suffering from Alzheimer's disease. Thus far, antimicrobial, antifungal and antioxidant activities have been confirmed for volatile oils extracted from field-grown plants. The main components of lavender volatile oil are monoterpenes, sesquiterpenes, linalool, linalool acetate, geraniol and borneol [12].

Infectious diseases are the main cause of global morbidity and mortality, especially in developing countries. Infectious diseases are caused by microorganisms, such as bacteria, viruses, parasites or fungi; the diseases that can be spread, directly or indirectly, from one person to another [13]. Medicinal plants are a source of bioactive compounds that have antispasmodic and antioxidant properties, and their use as volatile oil is a very good choice. HACCP has become accepted internationally as the best way to ensure food security. In 2004, the European Union (EU) adopted several new food hygiene regulations, which have become mandatory on $(852 / 2004$ / EC) January 1,2006 . The new regulation involved all the food business operators to implement the procedures based on the HACCP principles [14].

Because the bioactive compounds added to fermented dairy products require more special processing conditions, the qualitative analysis tools used in this study are the risk class matrix, the Ishikawa diagram, and the SWOT analysis. The Ishikawa diagram is used to identify the causes that lead to hazards and contamination. With the risk matrix, each hazard falls into a risk class depending on severity and frequency. If the risk class is high, that hazard can become a critical point of control. It is necessary to apply corrective actions for each critical control point. These actions keep the danger within certain limits. To identify the strengths and weaknesses of a product as well as the opportunities and threats of the market is necessary to use the SWOT analysis.

\section{Materials and methods}

\subsection{Risk Matrix}

Identification of the risks means the determination of physical, chemical and biological agents that can pose a significant hazard. Specifying the frequency and severity of the hazard is the risk assessment [15]. Risk assessment is carried out using the risk matrix.

Table 1. Risk matrix [15]

\begin{tabular}{|c|c|c|c|}
\hline $\mathbf{S}$ & \multicolumn{3}{|c|}{$\boldsymbol{R C}$} \\
\hline $\boldsymbol{H}$ & 3 & 4 & 4 \\
\hline $\boldsymbol{M}$ & 2 & 3 & 4 \\
\hline $\boldsymbol{L}$ & 1 & 2 & 3 \\
\hline $\boldsymbol{F}$ & $\boldsymbol{L}$ & $\boldsymbol{M}$ & $\boldsymbol{R}$ \\
\hline
\end{tabular}

$\mathrm{RC}$ - risk classes; $\mathrm{S}$ - severity; $\mathrm{F}$ - frequency; $\mathrm{H}$ - high; $\mathrm{M}$ - medium; $\mathrm{L}$ - low 


\subsection{Critical control points identification}

A critical control point is an operation or a procedure that, if isn't kept under control, it generates an unacceptable risk. That risk has no possibility of subsequent correction. It is necessary for each critical control point to determine the ways and methods to ensure that the critical limits are not exceeded [16].

\subsection{Ishikawa diagram}

The Ishikawa diagram is also known as the fish chart or cause-effect diagram. This is used to identify the causes of quality problems. It has the shape of a fish skeleton, and its graphic representation consists of five oblique segments that rest on a horizontal axis [17].

\subsection{SWOT analysis}

SWOT (strengths, weaknesses, opportunities and threats) analysis is a method for investigating the internal and external environmental factors that influence a product or process. The main purpose of this analysis is to identify the strengths and weaknesses of a product or process, as well as the opportunities and threats of the external environment. Strengths are good features that a product possesses and weaknesses are features that disadvantage the product compared to other products. Opportunities are the external factors that help to develop the product and threats are external factors that have negative effects on the product [18].

By using the research tools presented above, we have proposed the following:

- Establishing the main critical control points that may occur during the process of making fermented dairy products with addition of bioactive compounds from medicinal plants. By identifying these critical control points, we can determine from the beginning which operation of the technological scheme require particular attention.

- By using the Ishikawa diagram we identified the main causes that lead to contamination. The Ishikawa diagram is required to be accomplished for each operation that is a potential critical point of control. If we know the causes for each critical control point, we manage to keep that operation under control and avoid contamination.

- The SWOT analysis is used to identify strengths and weaknesses of the product compared to those existing on the market. It is also important to know the opportunities and market threats. Using this chart we can determine what are the benefits of our product and what we need to improve it. At the same time, we are able to identify how we can promote products, but also what are the threats that can prevent consumers from choosing them.

\section{Results and discussions}

\subsection{Hazard identification}

The technological scheme for obtaining cow's milk yoghurt with the addition of bioactive compounds under laboratory conditions is shown in figure 1: 


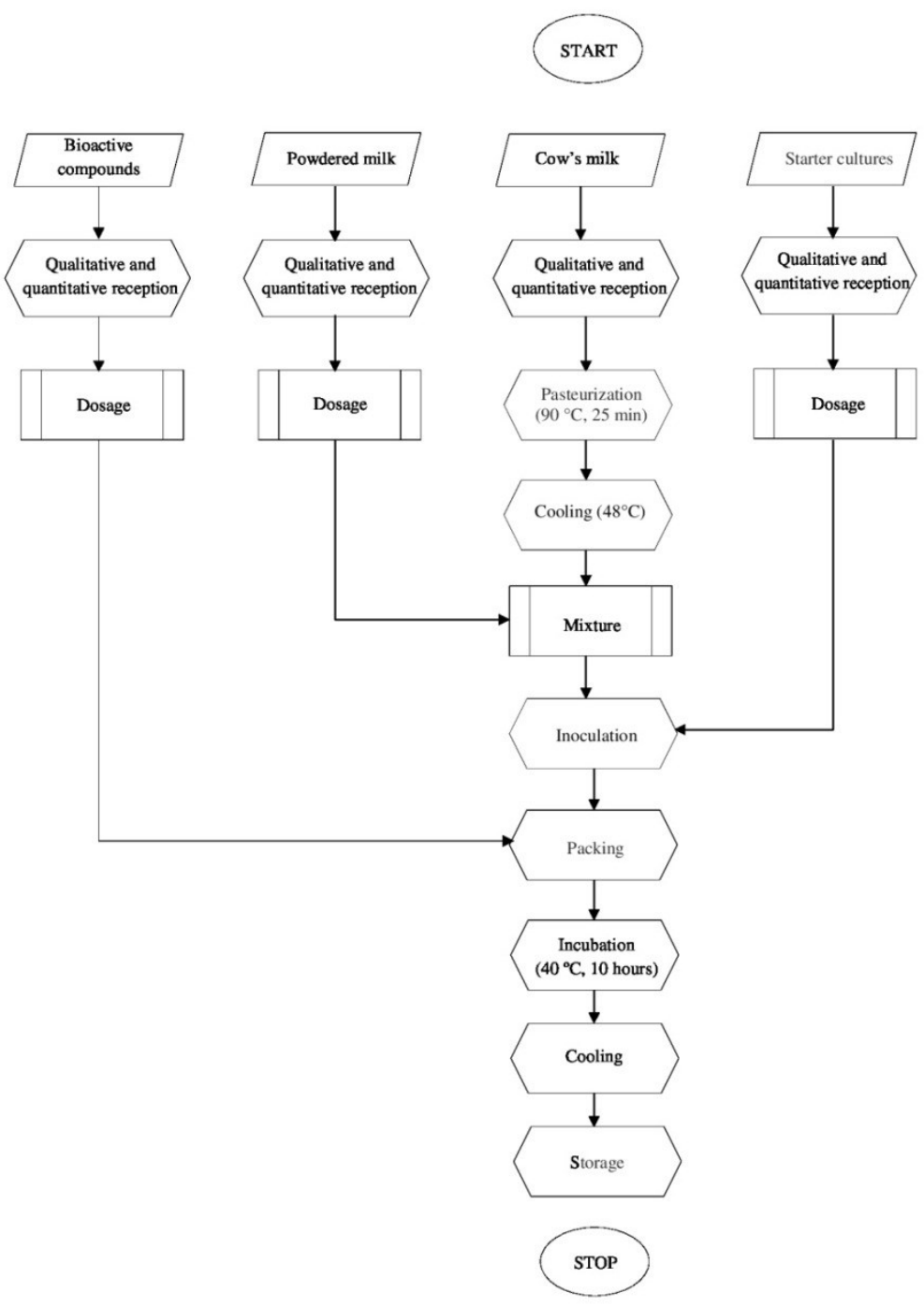

Fig. 1. Technological scheme for obtaining cow's milk yoghurt with the addition of bioactive compounds under laboratory conditions

We identified the dangers for each operation of the technological flow for obtaining yoghurt with bioactive compounds (table 2 and table 3 ).

Table 2. Hazard identification for qualitative and quantitative reception, pasteurization, cooling and inoculation

\begin{tabular}{|c|c|c|c|c|}
\hline No. & Process step & $\begin{array}{c}\text { Potential hazards } \\
\text { (physical, chemical, } \\
\text { microbiological) }\end{array}$ & Causes & $\begin{array}{c}\text { Preventive } \\
\text { measures }\end{array}$ \\
\hline 1. & $\begin{array}{c}\text { Qualitative and } \\
\text { quantitative } \\
\text { reception }\end{array}$ & Microbiological & $\begin{array}{c}\text { Pathogenic } \\
\text { bacteria: } \\
\text { Staphylococcus } \\
\text { aureus }\end{array}$ & $\begin{array}{c}\text {-Supplier selection } \\
\text {-Analysis bulletin } \\
\text {-Good hygiene } \\
\text { practices (GHP) }\end{array}$ \\
\hline
\end{tabular}




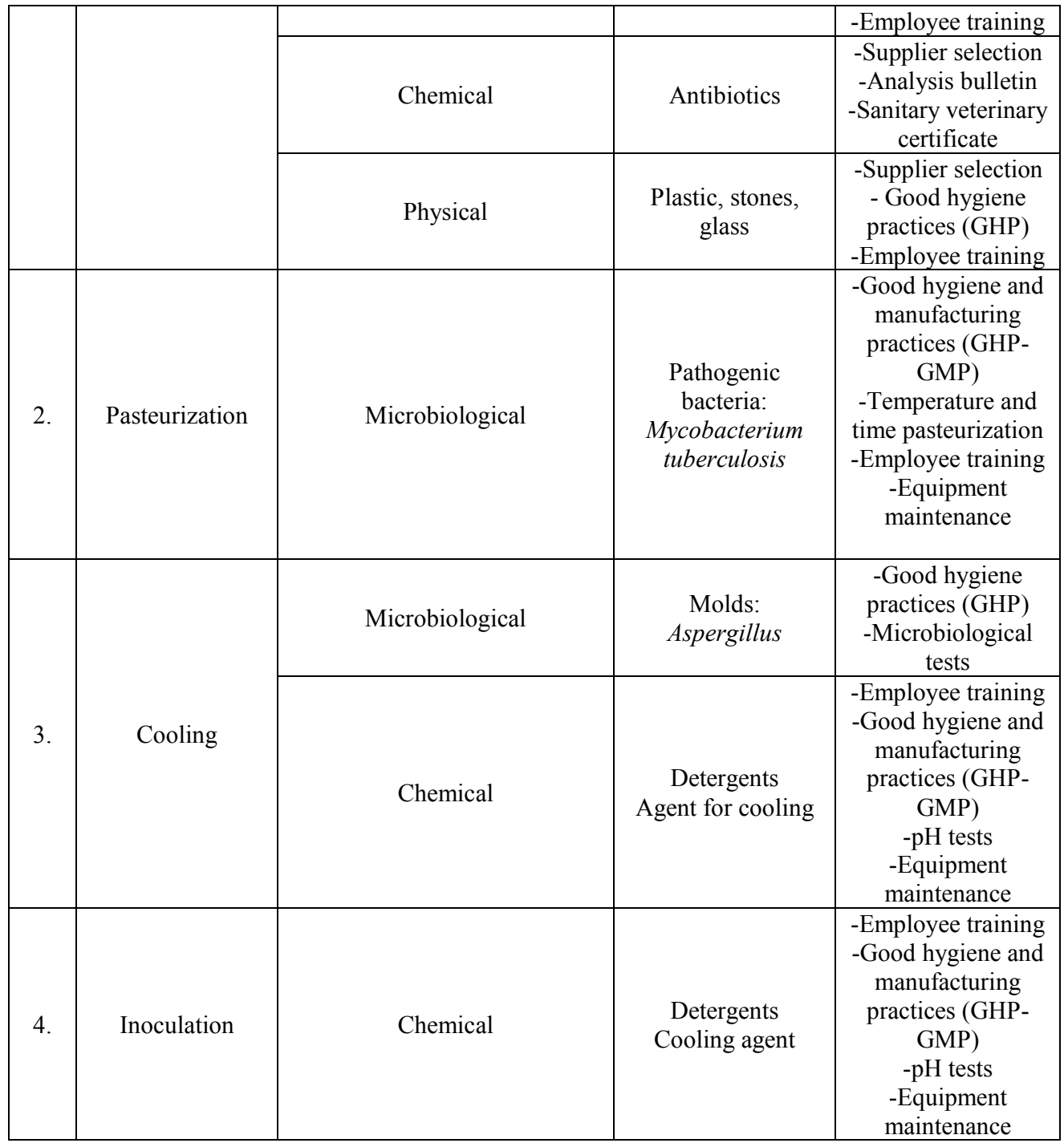

In Table 2 we identified the hazards for quantitative and qualitative reception, pasteurization, cooling and inoculation. Potential hazards are of three kinds: microbiological, chemical and physical. Depending on these types of hazards, we identified the causes, and then the prevention measures.

Within the quantitative and qualitative reception, all three types of hazards are present, and the presence of pathogenic bacteria, antibiotics and plastic, stones, glass is the most common cause.

In the case of pasteurization, the type of hazard identified is the microbiological one and the cause of its occurrence is pathogenic bacteria. In the cooling operation, the two types of hazards are microbiological and chemical, and the causes of the occurrence are molds and detergents or cooling agents. Chemical hazards occur in the inoculation operation, and the cause of their occurrence is detergents and cooling agents. 
Table 3. Hazard identification for packing, incubation and storage

\begin{tabular}{|c|c|c|c|c|}
\hline No. & Process step & $\begin{array}{l}\text { Potential hazards } \\
\text { (physical, chemical, } \\
\text { microbiological) }\end{array}$ & Causes & $\begin{array}{c}\text { Preventive } \\
\text { measures }\end{array}$ \\
\hline \multirow[t]{2}{*}{1.} & \multirow[t]{2}{*}{ Packing } & Microbiological & Coliform bacteria & $\begin{array}{c}\text {-Good hygiene and } \\
\text { manufacturing } \\
\text { practices (GHP- } \\
\text { GMP) } \\
\text {-Monitor the } \\
\text { parameters } \\
\text {-Employee training }\end{array}$ \\
\hline & & Physical & Foreign materials & $\begin{array}{c}\text {-Good } \\
\text { manufacturing } \\
\text { practices (GMP) } \\
\text {-Employee training }\end{array}$ \\
\hline \multirow[b]{2}{*}{2.} & \multirow[b]{2}{*}{ Incubation } & Microbiological & $\begin{array}{c}\text { Molds: } \\
\text { Aspergillus }\end{array}$ & $\begin{array}{l}\text {-Good hygiene } \\
\text { practices (GHP) } \\
\text {-Microbiological } \\
\text { tests }\end{array}$ \\
\hline & & Chemical & Cooling agent & $\begin{array}{l}\text {-Employee training } \\
\text {-Good hygiene and } \\
\text { manufacturing } \\
\text { practices (GHP- } \\
\text { GMP) } \\
\text {-pH tests } \\
\text {-Equipment } \\
\text { maintenance } \\
\end{array}$ \\
\hline \multirow[t]{2}{*}{3.} & \multirow[t]{2}{*}{ Storage } & Microbiological & Coliform bacteria & $\begin{array}{c}\text {-Good hygiene and } \\
\text { manufacturing } \\
\text { practices (GHP- } \\
\text { GMP) } \\
\text {-Monitor the } \\
\text { parameters } \\
\text {-Employee training }\end{array}$ \\
\hline & & Physical & Foreign materials & $\begin{array}{c}\text {-Good } \\
\text { manufacturing } \\
\text { practices (GMP) } \\
\text {-Employee training }\end{array}$ \\
\hline
\end{tabular}

In Table 3 we identified hazards for packing, incubation and storage operations. During the packaging operation two types of hazards were identified, microbiological and physical, and the causes of the occurrence are coliform bacteria and foreign materials.

Also, in incubation operation there are two types of hazards, microbiological and chemical, and the causes of the occurrence are molds and cooling agents. During the storage operation, microbiological and physical hazards can occur, and their causes are coliform bacteria and foreign materials.

\subsection{Risk evaluation. Risk Matrix}

We assigned each hazard to a risk class depending on severity and frequency. Depending on the hazards found, we used the matrix to identify risk classes. 
Table 4. Type of hazards and risk class for each stage of tehnological flow

\begin{tabular}{|c|c|c|c|c|}
\hline Stage & Hazard & Severity & Frequency & Risk class \\
\hline \multirow{2}{*}{$\begin{array}{c}\text { Qualitative and } \\
\text { quantitative } \\
\text { reception }\end{array}$} & Microbiological & $\mathrm{R}$ & $\mathrm{S}$ & 3 \\
\cline { 2 - 5 } & Chemical & $\mathrm{M}$ & $\mathrm{M}$ & 3 \\
\cline { 2 - 5 } & Physical & $\mathrm{M}$ & $\mathrm{S}$ & 2 \\
\hline Pasteurization & Microbiological & $\mathrm{R}$ & $\mathrm{M}$ & 4 \\
\hline \multirow{2}{*}{ Cooling } & Microbiological & $\mathrm{R}$ & $\mathrm{S}$ & 3 \\
\cline { 2 - 5 } & Chemical & $\mathrm{M}$ & $\mathrm{S}$ & 2 \\
\hline Inoculation & Chemical & $\mathrm{M}$ & $\mathrm{S}$ & 2 \\
\hline \multirow{2}{*}{ Packing } & Microbiological & $\mathrm{R}$ & $\mathrm{S}$ & 3 \\
\cline { 2 - 5 } & Physical & $\mathrm{M}$ & $\mathrm{S}$ & 2 \\
\hline \multirow{2}{*}{ Incubation } & Microbiological & $\mathrm{R}$ & $\mathrm{M}$ & 4 \\
\cline { 2 - 5 } & Chemical & $\mathrm{M}$ & $\mathrm{M}$ & 3 \\
\hline \multirow{2}{*}{ Storage } & Microbiological & $\mathrm{R}$ & $\mathrm{M}$ & 2 \\
\cline { 2 - 5 } & Physical & $\mathrm{M}$ & $\mathrm{S}$ & \\
\hline
\end{tabular}

Risk class:

1- Theoretical

2- We intervene through employee awareness procedures

3- General control procedures, supports a CP (critical point)

4- $\quad$ Specific control procedures, supports a CCP (critical control point)

In Table 4 we have assigned each hazard identified in a risk class. Assignment into a certain risk class was based on the severity and frequency of each hazard. The calculation of the risk class was made according to Table 1, the risk matrix.

There are four classes of risk, the first being purely theoretical, and the fourth one supports a critical point of control. Thus, increased attention should be paid to operations in higher risk classes ( 3 and 4 ) to avoid contamination.

\subsection{CP / CCP Identification: Critical Points (CP) / Critical Control Points (CCP)}

We identified the critical control points depending on the risk class.

In Table 5 we treated separately the operations from risk classes 3 and 4 . Class 3 supports a critical points (CP), and class 4 supports a critical control points (CCP). Class 4 is the most serious, as there is a very high risk of contamination if it is not kept under control (CCP).

Table 5. CCP Identification

\begin{tabular}{|c|c|c|c|}
\hline Stage & Hazard & Risk class & CCP/CP \\
\hline $\begin{array}{c}\text { Qualitative and } \\
\text { quantitative reception }\end{array}$ & Microbiological & 3 & CP1 \\
\cline { 2 - 4 } & Chemical & 3 & CP2 \\
\hline Pasteurization & Microbiological & 4 & CCP1 \\
\hline \multirow{2}{*}{ Cooling } & Microbiological & 3 & CP3 \\
\cline { 2 - 4 } & Chemical & 3 & CP4 \\
\hline Packing & Chemical & 3 & CP5 \\
\hline \multirow{2}{*}{ Incubation } & Microbiological & 4 & CP5 \\
\cline { 2 - 4 } & Chemical & 3 & CCP3 \\
\hline Storage & Microbiological & 4 & \\
\hline
\end{tabular}

The operations we have identified as critical control points are pasteurization, incubation and storage. For this reason we need to identify corrective actions to keep these critical control points within certain limits. 
Table 6. Corrective actions

\begin{tabular}{|c|c|c|c|c|c|c|}
\hline Stage & CСP & Causes & $\begin{array}{c}\text { Preventive } \\
\text { actions }\end{array}$ & $\begin{array}{c}\text { Critical } \\
\text { limits }\end{array}$ & $\begin{array}{c}\begin{array}{c}\text { Surveillance } \\
\text { methods }\end{array} \\
\end{array}$ & $\begin{array}{l}\text { Corrective } \\
\text { actions }\end{array}$ \\
\hline صี & CCP1 & $\begin{array}{l}\text { Insufficient } \\
\text { or exceeded } \\
\text { temperature }\end{array}$ & $\begin{array}{l}\text { Control } \\
\text { temperature }\end{array}$ & $\begin{array}{c}90^{\circ} \mathrm{C} \\
20-30 \\
\text { minutes }\end{array}$ & $\begin{array}{l}\text {-Check the } \\
\text { pasteurization } \\
\text { time } \\
\text {-Measuring the } \\
\text { pasteurization } \\
\text { temperature }\end{array}$ & $\begin{array}{l}\text {-Temperature } \\
\text { regulation } \\
\text {-Milk } \\
\text { recirculation } \\
\text {-Employee } \\
\text { training }\end{array}$ \\
\hline 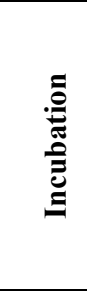 & $\mathrm{CCP} 2$ & $\begin{array}{l}\text { Insufficient } \\
\text { or exceeded } \\
\text { temperature }\end{array}$ & $\begin{array}{c}\text { Control } \\
\text { temperature }\end{array}$ & $\begin{array}{c}40^{\circ} \mathrm{C} \\
10 \text { hours }\end{array}$ & $\begin{array}{l}\text {-Measuring the } \\
\text { incubation } \\
\text { temperature } \\
\text {-Check the } \\
\text { incubation time }\end{array}$ & $\begin{array}{c}\text {-Incubator } \\
\text { adjustment } \\
\text {-Repair } \\
\text { incubator } \\
\text {-Temperature } \\
\text { regulation } \\
\text {-Employee } \\
\text { training } \\
\end{array}$ \\
\hline 窇 & CCP3 & $\begin{array}{l}\text { High } \\
\text { temperature }\end{array}$ & $\begin{array}{l}\text { Control } \\
\text { temperature }\end{array}$ & $2-4^{\circ} \mathrm{C}$ & $\begin{array}{l}\text {-Temperature } \\
\text { measurement }\end{array}$ & $\begin{array}{l}\text {-Temperature } \\
\text { regulation } \\
\text {-Employee } \\
\text { training }\end{array}$ \\
\hline
\end{tabular}

In Table 6 for each identified critical control point, we have identified the main causes of their occurrence, their preventive actions and their critical limits. We also identified surveillance methods to avoid critical limits, but also corrective actions that can be applied to each stage considered a critical point of control. These actions help us immediately correct the causes that lead to the critical control point and help us keep it under control.

\subsection{Ishikawa diagram}

Causes are the factors that lead to worsening of hazard [15]. We used the Ishikawa diagram to identify the causes.

\subsubsection{Ishikawa diagram for pasteurization}

Figure 2 shows the main causes that lead to contamination during the pasteurization operation. One of the causes that lead to contamination is non-compliance the time and temperature pasteurization. Another reason is the composition of the filtered milk. The lack of hygiene of pasteurizer, the dirty hands of the workers and the effectiveness of pasteurizer are other causes that lead to the emergence of hazards. 


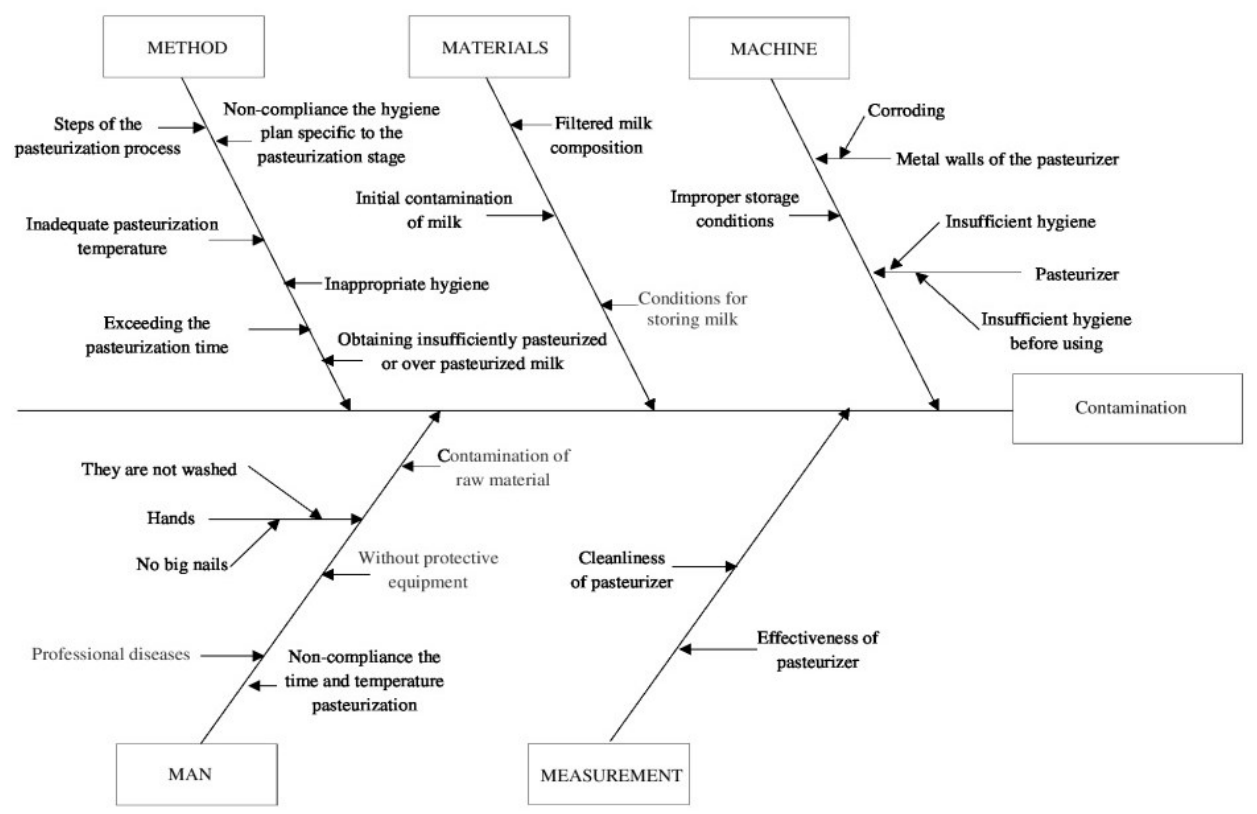

Fig. 2. Ishikawa diagram for pasteurization

\subsubsection{Ishikawa diagram for incubation}

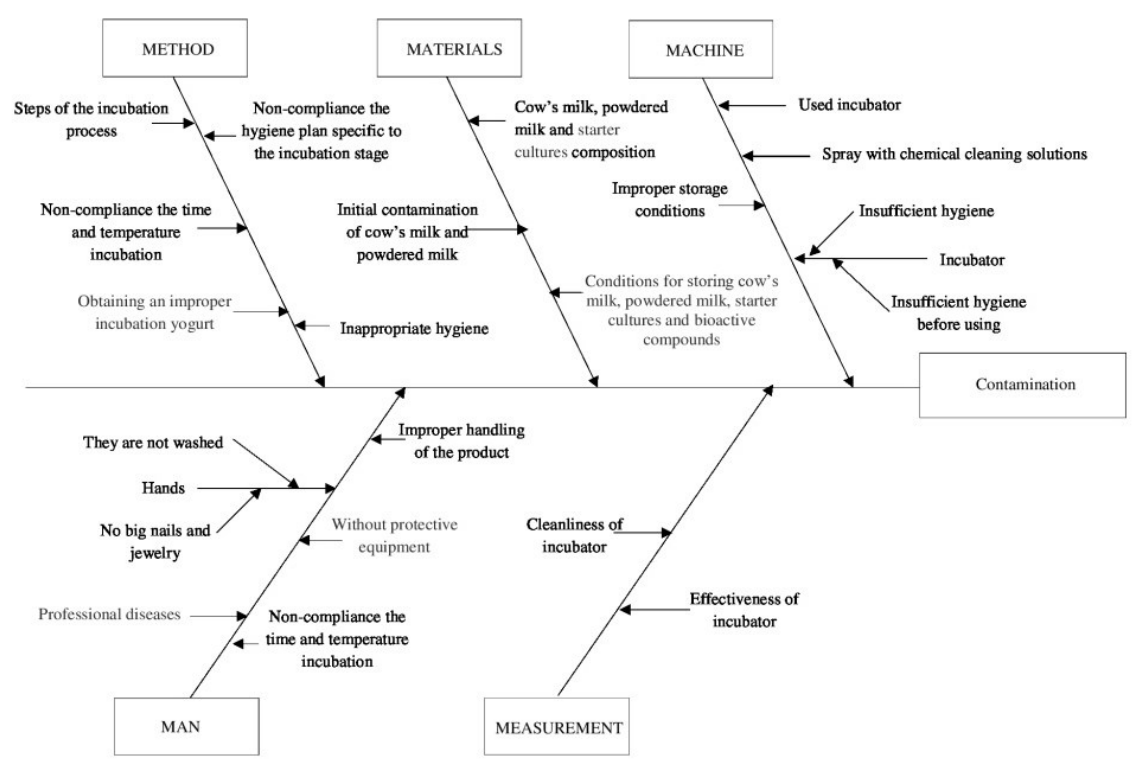

Fig. 3. Ishikawa diagram for incubation

Figure 3 shows the main causes that lead to contamination during the incubation operation. One of the causes that lead to contamination is non-compliance the time and 
temperature incubation. Another reason is the conditions for storing cow's milk, powdered milk, starter cultures and bioactive compounds. The insufficient hygiene of incubator, dirty hands of the workers and the effectiveness of incubator are other causes that lead to the emergence of hazards.

\subsection{SWOT analysis}

It is very important to know the strengths and weaknesses for a product compared to other products. It is also important to know the opportunities and market threats. For this reason, it is necessary to achieve a SWOT analysis.

Table 7. SWOT analysis

\begin{tabular}{|c|c|}
\hline \multicolumn{2}{|c|}{ SWOT analysis } \\
\hline $\begin{array}{l}\text { Strengths } \\
\text {-benefits to health } \\
\text { - the quality of raw materials and finished } \\
\text { products } \\
\text { - antioxidant activity of bioactive compounds } \\
\text { - extending the shelf life of the finished product } \\
\text { due to the antiseptic capacity of the bioactive } \\
\text { compounds } \\
\text { - replacement of food additives due to bioactive } \\
\text { compounds } \\
\text { - making products with a great and innovative } \\
\text { taste }\end{array}$ & $\begin{array}{l}\text { Weaknesses } \\
\text { - some people have lactose intolerance } \\
\text { - lack of diversity of dairy products } \\
\text { - high price of the finished product }\end{array}$ \\
\hline $\begin{array}{l}\text { Opportunities } \\
\text {-growing consumer interest for healthy food } \\
\text { products } \\
\text { - the possibility of developing new products and } \\
\text { attracting new customers }\end{array}$ & $\begin{array}{l}\text { Threats } \\
\text { - high cost of raw materials } \\
\text {-changes of customer tastes and preferences } \\
\text { - changes in customer requirements }\end{array}$ \\
\hline
\end{tabular}

In Table 6, we have determined the strengths and weaknesses of the product, as well as opportunities and market threats. As strengths compared to other fermented dairy products existing on the market, the most important are the health benefits due to the dairy products proprieties and the bioactive components of medicinal plants. The bioactive components of these plants have antioxidant properties, and their antiseptic properties lead to the extended shelf life of the finished product. By using bioactive components, it is possible to exclude some of the food additives, especially those used for preservation. The taste and smell of the finished product, thanks to the bioactive components, leads to the creation of an innovative dairy product. The weaknesses of this product are lactose intolerance of some people, their lack of diversity, and the high price of the finished product. The most important market opportunity is to increase consumers' interest for healthy food.

The possibility of developing new products can attract new consumers. The most important threat to the market is the high cost of raw materials. Changes in consumer preference and taste, as well as changes to their requirements, may also be taken into account. 


\section{Conclusions}

Fermented dairy products are highly appreciated due to the benefits that bring to consumers health. They can be eaten at an early age and the most famous dairy product from this category is yogurt. Extracts from different medicinal plants have been used since antiquity, and following several studies over the years, it has come to the conclusion that they have many beneficial effects on many diseases. Fermented dairy products with the addition of bioactive components bring a contribution to consumer's health due to the antioxidant and antiseptic properties they possess. These properties are due to extracts of basil, mint, fennel and lavender.

Because the bioactive compounds added to fermented dairy products require more special processing conditions, the qualitative analysis tools used in this study are the risk class matrix (table 1), the Ishikawa diagram, and the SWOT analysis. By identifying the hazards, we have determined the causes of occurrence for each stage of the technological production process of cow's milk yoghurt with the addition of bioactive components from medicinal plants (table 2 and table 3). After identifying the hazards, depending on severity and frequency, we placed each hazard in risk classes (table 4). By assessing the risks, we have been able to determine the critical control points and the specific corrective actions for them (table 5 and table 6). With the Ishikawa diagram, we identified the causes that lead to aggravation of the hazards specific to the pasteurization and incubation operation (figure 2 and figure 3). Through the SWOT analysis we identified the strengths, weaknesses of the product and market opportunities and threats (table 7). The most important strength of the product is the benefits for consumer's health and the weakest point is the inability of some people to consume dairy products. An important market opportunity is the growing consumer interest for healthy food products, and an important threat is the changes in customer requirements, tastes and preferences.

In conclusion, we described a procedure for the analysis the quality of dairy fermented products with the addition of bioactive components, and with the help of qualitative analysis tools, we achieved our proposed objective.

\section{References}

1. K. J. Aryana, D. W. Olson, J. Dairy Sci. 100, 9987-10013 (2017)

2. J. Deepa, P. Rajkumar, P. Preetha, Intl. J. Food. Ferment. Technol. 35, 397-403 (2016)

3. A. Dabija, G.G. Codina, S. Ropciuc, A.M. Gatlan, L. Rusu, J. Food Qual. 213, 1377-1391 (2018)

4. A. Haagen-Smit, Eng. Sci. 24, 7-11 (1961)

5. M. Chenni, D.El. Abed, N. Rakotomanomana, X. Fernandez, Molecules. 21, 1-16 (2016)

6. A.B. Falowo, F.E. Mukumbo, E.M. Idamokoro, A.J. Afolayan, V. Muchenje, Int. J. Food Sci. Tech. 2019, 1-8 (2019)

7. B. Sayed-Ahmad, E. Straumite, M. Šabovics, Z. Kruma, O. Merah, Z. Saad, A. Hijazi, T. Talou, Proc. Latv. Acad. Sci. Sect. B Nat. Exact Appl. Sci. 71, 509-514 (2017)

8. K.R. Pande, R. Preetha, Asian J Chem. 29, 711-714 (2017)

9. C. Oroian, I. Covrig, A. Odagiu, C. Mălinaş, C. Moldovan, A. Fleşeriu, Not. Bot. Horti. Agrobo. 45, 576-581 (2017)

10. R. Singh, M.A.M. Shushni, A. Belkheir, Arab J. Chem. 8, 322-328 (2015)

11. L. Caputo, M.D. Reguilon, J. Mińarro, V. De Feo, M. Rodriguez-Arias, Molecules. 23, 1-15 (2018)

12. D. Andrys, D. Kulpa, M. Grzeszczuk, M. Bihun, A. Dobrowolska, Folia. Hort. 29, 161-180 (2017)

13. S. Salma, L. Ramakrishnan, J. Vinothini, Asian J. Pharm. Clin. Res. 11, 11-13 (2018)

14. A. Musaj, B. Bijo, A. Hoxha, V. Gjinovci, Maced. J. Anim. Sci. 2, 313-320 (2012)

15. I. Bratu, HACCP de la teorie - la practică, 35-45 (2002) 
16. K. Hoolasi, A HACCP Study on Yoghurt Manufacture, 1-68 (2005)

17. R. Cahyana, IOP Conf. Ser. Mater. Sci. Eng. 434, 1-6 (2018)

18. Y. Liu, T. Liu, A. Agyeiwaa, Y. Li, IOP Conf. Ser. Earth Environ. Sci. 170, 1-6 (2018) 